\title{
Bostrycin inhibits proliferation of human lung carcinoma A549 cells via downregulation of the PI3K/Akt pathway
}

Wei-Sheng Chen ${ }^{1+}$, Jun-Na Hou ${ }^{1+}$, Yu-Biao Guo ${ }^{1 *}$, Hui-Ling Yang ${ }^{2}$, Can-Mao Xie ${ }^{1}$, Yong-Cheng Lin ${ }^{3}$, Zhi-Gang She ${ }^{3}$

\begin{abstract}
Background: Bostrycin is a novel compound isolated from marine fungi that inhibits proliferation of many cancer cells. However, the inhibitory effect of bostrycin on lung cancers has not been reported. This study is to investigate the inhibitory effects and mechanism of bostrycin on human lung cancer cells in vitro.

Methods: We used MTT assay, flow cytometry, microarray, real time PCR, and Western blotting to detect the effect of bostrycin on A549 human pulmonary adenocarcinoma cells.

Results: We showed a significant inhibition of cell proliferation and induction of apoptosis in bostrycin-treated lung adenocarcinoma cells. Bostrycin treatment caused cell cycle arrest in the G0/G1 phase. We also found the upregulation of microRNA-638 and microRNA-923 in bostrycin-treated cells. further, we found the downregulation of p110 $\alpha$ and p-Akt/PKB proteins and increased activity of p27 protein after bostrycin treatment in A549 cells.

Conclusions: Our study indicated that bostrycin had a significant inhibitory effect on proliferation of A549 cells. It is possible that upregulation of microRNA-638 and microRNA-923 and downregulaton of the PI3K/AKT pathway proteins played a role in induction of cell cycle arrest and apoptosis in bostrycin-treated cells.
\end{abstract}

\section{Background}

Lung cancer is the most common type of cancer worldwide. Despite recent advances in surgical techniques and chemotherapy/radiotherapy strategies, the long-term survival rates remain poor. There is therefore an urgent need to develop new therapeutic strategies in order to significantly improve the prognosis in lung cancer patients. Growth factor signaling pathways have been shown to be important targets in lung cancer therapy. Targeting such intracellular pathways that regulate proliferation, apoptosis, metastasis and resistance to chemotherapy represents an important therapeutic strategy for lung cancer [1].

Marine microorganisms can grow under adverse conditions such as low temperatures, high pressures, and poor nutrition. The diversity of biological activities in these environments exceeds those of land organisms.

\footnotetext{
*Correspondence: yubiaog@163.com

+ Contributed equally

'Department of Pulmonary and Critical Care Medicine, the First Affiliated

Hospital of Sun Yat-Sen University, Guangzhou 510080, China

Full list of author information is available at the end of the article
}

Some metabolites from these marine microorganisms have novel structures and biological activities including anticancer, antiviral and immune enhancement properties. A recent study on marine pharmacology coordinated by multiple countries demonstrated antitumor activity in a number of natural products derived from marine invertebrates, algae, fungi, and bacteria, although the mechanisms of action are still unknown [2].

Bostrycin, a novel compound isolated from marine fungi in South China Sea, has been shown to inhibit cell growth in in prostate cancer and gastric cancer $[3,4]$. However, since the antitumor effect of bostrycin in lung cancer is not known, we explored the effect of bostrycin treatment in lung cancer cells and investigated the mechanisms underlying the inhibitory effect of bostrycin in lung cancers.

\section{Materials and methods \\ Cell line and cell culture}

The human pulmonary adenocarcinoma cell line A549 was obtained from the Cell Bank of the Animal Experiment Center, North School Region, Sun Yat-Sen University.
C Biomed Central

() 2011 Chen et al; licensee BioMed Central Ltd. This is an Open Access article distributed under the terms of the Creative Commons Attribution License (http://creativecommons.org/licenses/by/2.0), which permits unrestricted use, distribution, and reproduction in any medium, provided the original work is properly cited. 
Cells were cultured in DMEM medium (low glucose) supplemented with $10 \%$ newborn calf serum at $37^{\circ} \mathrm{C}$ with $5 \%$ $\mathrm{CO}_{2}$. Cells were digested with $0.25 \%$ trypsin and subcultured at $70 \%$ to $80 \%$ confluence Exponentially growing A549 cells were used for all assays.

\section{Test compound}

Bostrycin (hydroxy-methoxy-tetrahydro-5-methyl anthracene dione), a novel compound isolated from marine fungi in P.R. China, was supplied by Marine Microorganism Laboratory, Institute of Chemistry and Chemical Engineering, Sun Yat-Sen University. The chemical structure of bostrycin is shown inAdditional file 1, Figure S1.

\section{Major reagents}

Newborn calf serum, DMEM (low glucose), 0.25\% trypsin digest, and Trizol reagent were purchased from GIBCO (Invitrogen Corporation, Carlsbad, CA, USA). MTT and DMSO were obtained from Sigma Corporation. Mouse anti-human phospho-Akt monoclonal antibody (mAb), rabbit anti-human $\mathrm{p} 110 \alpha \mathrm{mAb}$, rabbit anti-human $\mathrm{p} 27$ $\mathrm{mAb}$, horseradish peroxidase (HRP)-conjugated goat anti-mouse IgG (secondary antibody), HRP-conjugated goat anti-rabbit IgG (secondary antibody), and prestained protein molecular weight marker were purchased from Cell Signaling Technology (USA).

\section{Measurement of cell growth inhibition by MTT assay}

A549 cells were seeded in 96 -well plates $\left(5 \times 10^{3}\right.$ cells per well) and treated with bostrycin (10, 20, and $30 \mu \mathrm{mol} / \mathrm{L}$ ). Negative control wells (containing cells but not bostrycin), and the blank control (only medium) were plated with 6 replicates each. Untreated and treated cells were cultured at $37^{\circ} \mathrm{C}$ with $5 \% \mathrm{CO}_{2}$ for 12 hours. MTT solution $(20 \mu \mathrm{L})$ was added to each well and mixed; the wells were then incubated for an additional 4 hours. Culture supernatant was removed, DMSO $(150 \mu \mathrm{L})$ was added to each well and vortexed at low speed for $10 \mathrm{~min}$ utes to fully dissolve the blue crystals. Absorbance was measured at $570 \mathrm{~nm}\left(\mathrm{~A}_{570}\right)$ and the percentage of growth inhibition of A549 cells was calculated at each time point and for each concentration of bostrycin according to the following formulae: \% cell survival $=($ A570bostrycin group - A570blank)/(A570negative - A570blank) $\times 100 \%$ and $\%$ cell growth inhibition $=1-\%$ cell survival. Half maximal inhibitory concentration (IC50) values at respective times were then calculated using linear regression.

Cell cycle and apoptosis rate assayed by flow cytometry A549 cells were cultured in 6 -well plates $\left(1.5 \times 10^{5}\right.$ cells per well) and treated with different concentrations (5, 10 , and $20 \mu \mathrm{mol} / \mathrm{L}$ ) of bostrycin or complete DMEM medium (for the control group) and incubated for 24 , 48 or 72 hours. Culture supernatant from each group was pooled and the cells were fixed for $12 \mathrm{~h}$ with $1 \mathrm{ml}$ of $75 \%$ ethanol $\left(10^{6}\right.$ cells $\left./ \mathrm{ml}\right)$ and transferred to $2 \mathrm{~mL}$ Eppendorf tubes for flow cytometry and propidium iodide (PI) staining. For PI staining, the cells were washed twice with cold PBS and centrifuged at $1000 \mathrm{~g}$ for $5 \mathrm{~min}$. The pellet was washed twice in cold $0.1 \%$ Triton $\mathrm{X}-100 \mathrm{PBS}$ and incubated at room temperature for 30 minutes with $300 \mu \mathrm{L}$ DNA dye (containing $100 \mu \mathrm{g} / \mathrm{mL}$ propidium iodide and $20 \mathrm{U} / \mathrm{mL}$ RNase; Sigma Corporation). Flow cytometry analysis (BECKMAN-COULTER Co., USA) was performed. The cells were collected for the calculation of DNA amount for cell cycling analysis using a MULTYCYCLE software (PHEONIX, Co. USA). The extent of apoptosis was analyzed and quantified using WinMDI version 2.9 (Scripps Research Institute, La Jolla, CA, USA).

\section{Differential expression of microRNAs Preparation of total RNA sample}

A549 cells were cultured in 6 -well plates $\left(1.5 \times 10^{5}\right.$ cells per well) and treated for $72 \mathrm{~h}$ with $10 \mu \mathrm{mol} / \mathrm{L}$ bostrycin for the bostrycin group or with complete medium for the control group. The cells were lysed in $1.5 \mathrm{~mL}$ of Trizol reagent and total RNA was prepared according to the manufacturer's instructions.

\section{Microarray}

Microarray analysis was performed using a service provider (LC Sciences, USA). The assay used 2-5 $\mu$ g total RNA, which was size-fractionated using a YM-100 Microcon centrifugal filter (SIGMA). The small RNAs (<300 nucleotides) isolated were 3' extended using poly (A) polymerase. An oligonucleotide tag was then ligated to the poly(A) tail for fluorescent dye staining. Two different tags were used for the two RNA samples in dualsample experiments. Hybridizations were performed overnight on a $\mu$ Paraflo microfluidic chip using a microcirculation pump (Atactic Technologies, Houston, TX, USA). Each detection probe on the microfluidic chip consisted of a chemically modified nucleotide-coding segment complementary to a target microRNA (miRBase; http://microrna.sanger.ac.uk/sequences/) or other RNA (control or customer-defined sequences). The probe also contained a spacer segment of polyethylene glycol to separate the coding segment from the substrate. The detection probes were made by in situ synthesis using PGR (photogenerated reagent chemistry). The hybridization melting temperatures were balanced by chemical modifications of the detection probes. Hybridization was done in $100 \mu \mathrm{L} 6 \times$ saline-sodium phosphate-EDTA buffer $\left(0.90 \mathrm{M} \mathrm{NaCl}, 60 \mathrm{mMNa}_{2} \mathrm{HPO}_{4}\right.$, and $6 \mathrm{mM}$ EDTA, pH 6.8) containing 25\% formamide at $34^{\circ} \mathrm{C}$ and fluorescence labeling with tag-specific $\mathrm{Cy} 3$ and 
Cy5 dyes was used for detection. Hybridization images were collected using a laser scanner (GenePix 4000B, Molecular Device) and digitized using Array-Pro image analysis software (Media Cybernetics). Data were analyzed by first subtracting the background and then normalizing the signals using a LOWESS filter (locally weighted regression). For two-color experiments, the ratio of the two sets of detected signals (log 2 transformed; balanced) and $P$ values of the $t$ test were calculated. Differentially detected signals were those with $P<0.01$.

\section{$R T-P C R$}

RT-PCR was performed using the TaqMan MicroRNA Reverse Transcription Kit (LC Sciences, USA) and the ABI PRISM 7000 Sequence Detection System (Life Technologies Corporation, Carlsbad, CA, USA). $2 \mu \mathrm{g}$ RNA was used to synthesize single stranded cDNA according to the manufacturer's instructions. Real time PCR was performed to amplify the cDNA with the TaqMan Universal PCR Master Mix (LC Sciences, USA) as follows: amplification for 30 cycles at $94^{\circ} \mathrm{C}$ for $0.5 \mathrm{~min}$, annealing at $55^{\circ} \mathrm{C}$ for $0.5 \mathrm{~min}$, and extension at $72^{\circ} \mathrm{C}$ for $0.5 \mathrm{~min}$; and then terminal elongation step at $72^{\circ} \mathrm{C}$ for $10 \mathrm{~min}$ and a final holding stage at $4^{\circ} \mathrm{C}$. The amplification plots were viewed and the baseline and threshold values (as indicated in the instrument user guide) were set to analyze the results. The relative miRNA expression was calculated using $2^{-\Delta \Delta C t}$ where $\Delta C t$ is the difference between target miRNA or reference miRNA Ct values in the treated and control samples. $\Delta \Delta \mathrm{Ct}$ is the difference between the above two $\Delta \mathrm{Ct}$ from target miRNA and reference miRNA.

\section{Western blotting}

A549 cells (cultured in 6-well plate at $1.5 \times 10^{5}$ cells per well) were treated with $10 \mu \mathrm{mol} / \mathrm{L}$ bostrycin for 12,24 , 48 , and 72 hours, and total proteins were extracted. Protein samples were separated by SDS-PAGE and electrophoretically transferred onto a polyvinylidene difluoride membrane (Millipore, USA). The membrane was blocked overnight at 4 degree in TBS-Tween 20 (TBST) buffer containing $5 \%$ skimmed milk powder. The membrane was washed with TBST $(3 \times 8$ minutes $)$. Membranes were then incubated overnight at $4^{\circ} \mathrm{C}$ in primary antibody $\left(125 \mu \mathrm{L} / \mathrm{cm}^{3}\right.$; diluted $\left.1: 1,000\right)$ with gentle shaking. The membranes were washed with TBST ( $3 \times 8$ minutes $)$ and incubated for $1 \mathrm{~h}$ at room temperature in HRP-conjugated secondary antibody $\left(125 \mu \mathrm{L} / \mathrm{cm}^{3}\right.$; diluted $\left.1: 2,500\right)$. The membranes were washed with TBST $(3 \times 8$ minutes $)$ and protein signals were detected by chemiluminescence kit (Cell signaling Technology, USA).

\section{Statistical analysis}

Normally distributed continuous variables were compared by one-way analysis of variance (ANOVA). When a significant difference between groups was apparent, multiple comparisons of means were performed using the Bonferroni procedure with type-I error adjustment. Data are presented as means \pm SD. All statistical assessments were two-sided and evaluated at the 0.05 level of significant difference. Statistical analyses were performed using SPSS 13.0 statistics software (SPSS Inc, Chicago, IL)

\section{Results}

Bostrycin inhibited the proliferation of A549 cells

First, we used the MTT assay to detect effect of bostrycin on A549 cell proliferation. There was a dose-dependent and time-dependent inhibition of A549 cell proliferation by bostrycin (Figure 1) with an optimal linear relationship seen between $10-30 \mu \mathrm{M}$ of bostrycin. This indicated that bostrycin could significantly inhibit A549 cell proliferation in vitro.

\section{Bostrycin induced cell cycle arrest and apoptosis in A549 cells}

Then, we used flow cytometry to determine cell cycle distribution and apoptosis in A549 cells exposed to different concentrations of bostrycin for 24, 48, and 72 hours. We showed a significant increase in the number of $G_{0} / G_{1}$ phase cells and a decrease in the number of $S$ and $G_{2} / M$ phase cells after 72 hours of bostrycin treatment (Figure 2A). We also used propidium iodide staining to show that bostrycin induced apoptosis of

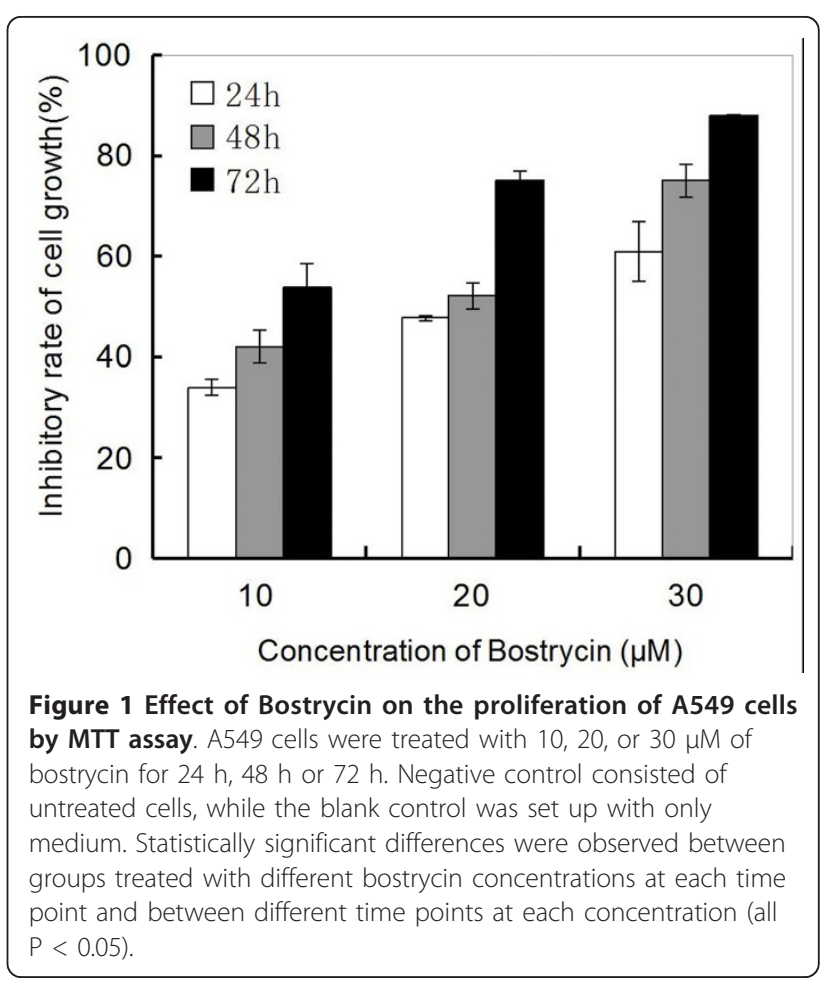




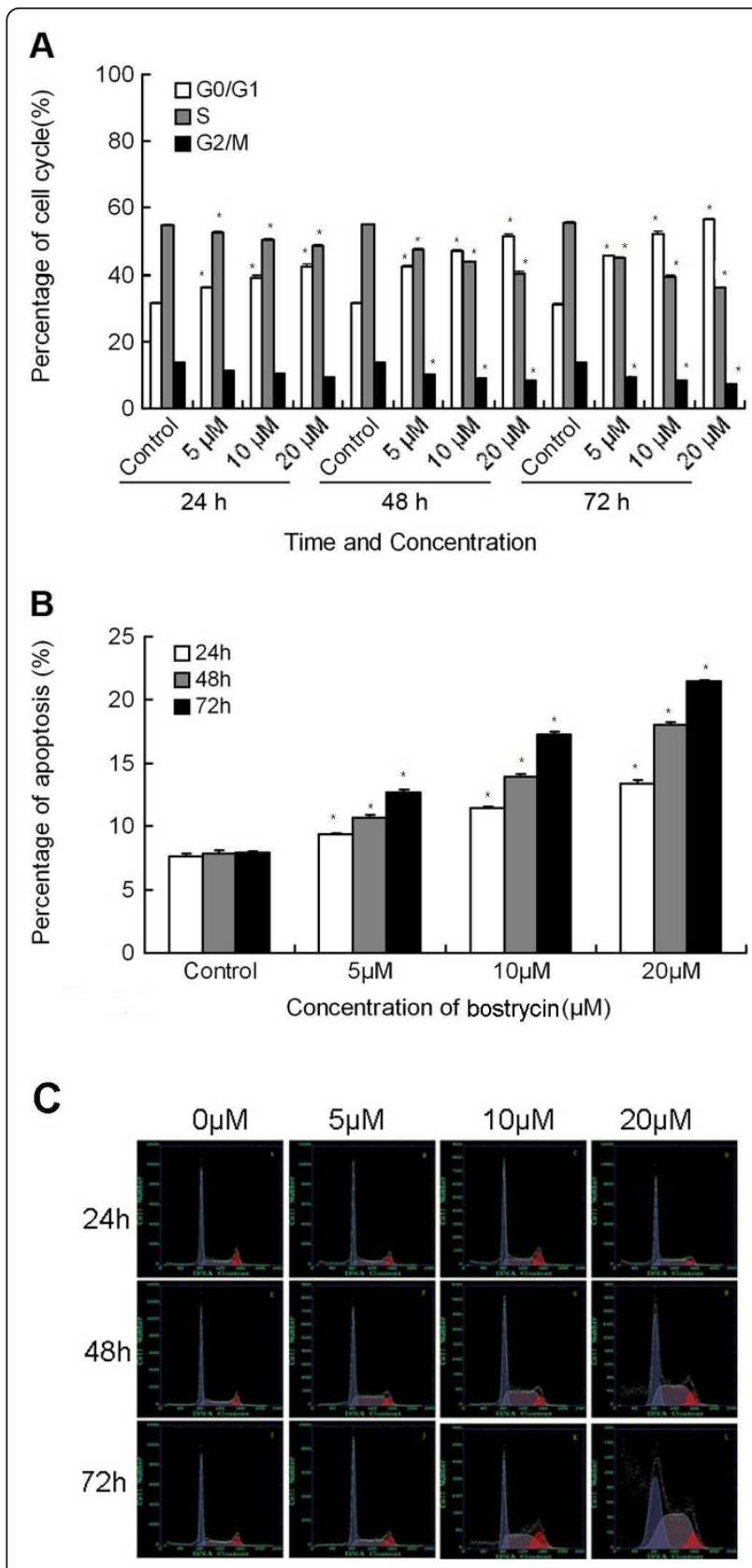

Figure 2 Effect of Bostrycin on cell cycle and apoptosis detected by flow cytometry. A549 cells were treated with $0,5,10$ or $20 \mu \mathrm{M}$ of bostrycin for $24 \mathrm{~h}, 48 \mathrm{~h}$ or $72 \mathrm{~h}$. A) represents the percentage of A549 cells at different phases of the cell cycle at different time points and at different concentrations of bostrycin; B) represents the percentage of apoptotic A549 cells at different time points and at different concentrations of bostrycin; C) shows representative flow cytometry plots. *Indicates a statistically significant difference between the given group and its corresponding control group. Pair-wise multiple comparisons between groups were determined using Bonferroni's test with $\alpha=0.017$ adjustment.
A549 cells in a dose-dependent and time-dependent manner (Figure 2B). Figure $2 \mathrm{C}$ shows the flow cytometry data of cells treated with different concentrations of bostrycin for $24 \mathrm{~h}, 48 \mathrm{~h}$ and $72 \mathrm{~h}$.

\section{Analysis of microRNA expression in A549 cells by microarrays and real-time RT-PCR}

We used a gene chip probe techniques to detect changes in microRNA expression in bostrycin-treated A549 cells when compared with untreated cells. We found a statistically significant difference in the expression of fifty-four microRNAs (data not shown). We selected microRNA-638 and microRNA-923 for further validation with real-time RT-PCR since these two microRNAs showed the most significant difference. We used RT-PCR to demonstrate a significant upregulation in the levels of microRNA-638 and microRNA-923 in bostrycin-treated A549 cells. These data were consistent with our microarray analysis (Figure 3).

\section{Detection of $\mathrm{p} 110 \alpha, \mathrm{p}-\mathrm{Akt}$, and $\mathrm{p} 27$ levels in bostrycin-} treated cells

Finally, we detected the possible signal pathway involved in the effects of bostrycin on A549 cells. We showed by western blots that there was a decrease in the expression of p110 $\alpha$ protein over time in bostrycin-treated A549 cells. Although there was an increase in the expression of p-Akt protein in cells treated with bostrycin for 12 hours, when compared with cells at the 0 hour time point, we showed a gradual decrease in p-Akt levels over time, with the most obvious reduction at 48 hours. We also showed a time-dependent increase in the levels of p27 protein in bostrycin-treated cells (Figure 4).

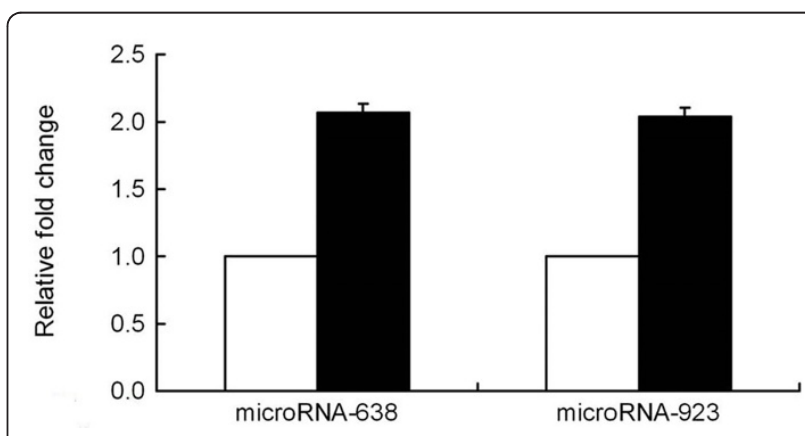

Figure 3 Relative change in expression of microRNA-638 and microRNA-923 in A549 cells treated with bostrycin detected by microRNA real time PCR. A549 cells were treated with $10 \mu \mathrm{M}$ Bostrycin for $72 \mathrm{~h}$ and total RNA was isolated for microRNA real time PCR assay. Expression levels of microRNA-638 and microRNA923 were determined as described. Untreated A549 cells were used as control. Each condition was repeated 4 times. 


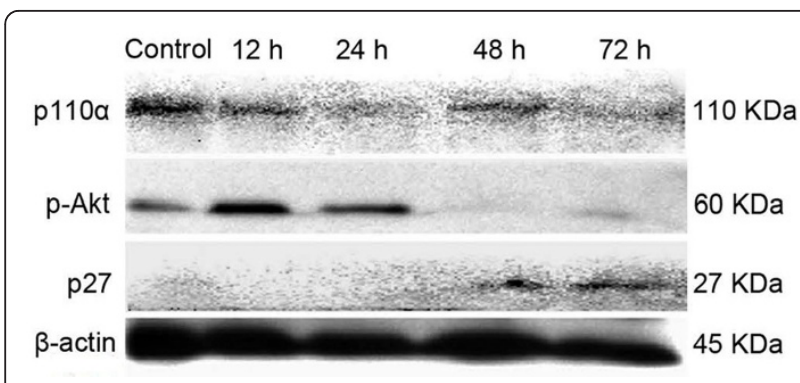

Figure 4 Effects of Bostrycin on intracellular expression of p110 $\alpha$, p-Akt and p27 in A549 cells. A549 cells were treated with $10 \mathrm{~mol} / \mathrm{L}$ bostrycin for $12,24,48$, or 72 hours. Cells were harvested, total proteins were extracted and immunoblotted for p110 $\alpha, \mathrm{p}$-Akt and p27. Untreated A549 cells were used as a control. Beta-actin was used as loading control.

\section{Discussion}

In this study, we demonstrated that bostrycin, a novel compound isolated from marine fungi in the South China Sea, inhibited cell proliferation, blocked cell cycle progression, and promoted apoptosis of lung cancer A549 cells. Our data also suggested that the PI3K/AKT signaling pathway may play a role in bostrycin-mediated inhibition of cell proliferation. Although bostrycin was previously shown to effectively inhibit cell growth and promote apoptosis in prostate cancer and gastric cancer $[3,4]$, it has not been used in lung cancer cells. To our knowledge, ours is the first study demonstrating that bostrycin significantly inhibited the growth of A549 cells in a concentration- and time-dependent manner.

Regulation of the cell cycle and apoptosis is a major determinant dictating the development and progression of a number of cancers. PI3K/AKT inhibitors such as Tipifarnib, cause cell cycle arrest at the $G_{1}$ or $G_{2} / M$ phase and induce apoptosis of human lung cancer cells $[5,6]$ Our data were consistent with this study and showed that bostrycin treatment induced downregulation of PI3K/AKT signal pathway proteins, caused $G_{0} / G_{1}$ cell cycle arrest and promoted apoptosis in A549 cells.

PI3K is composed of a p110 2 subunit and p85 subunit and the PI3K/AKT signaling pathway has been shown to play a role in the development and progression of lung cancer [7]. Increased Akt activity has been reported in the bronchial endothelial cells of long-term smokers $[8,9]$ and persistently high levels of activated Akt was shown in bronchial endothelial cells from malignant tumors or precancerous lesions. Akt activation is thought to be related to poor prognosis of patients with lung cancer [10-12] and may be an important molecular target for treatment of lung cancer.

The PI3K/AKT signaling pathway inhibits apoptosis by inactivating important members of the apoptotic cascade, including caspase-9, forkhead, and proapoptotic
Bad [13-15] and by upregulating the transcription and translation of antiapoptotic genes via NF $\kappa \mathrm{B}$ [16] and cell cycle genes like cyclin D1 and p27 [17]. The p27 gene, a tumor suppressor, encodes a late $G_{1}$ cyclin-dependent kinase inhibitor, whose activity is dependent on phosphorylation-dependent cytoplasmic translocation [18]. The PI3K/AKT pathway regulates p27 activity by 1 ) directly phosphorylating it at Thr159' resulting in cytoplasmic translocation and inactivation of $\mathrm{p} 27$ or 2 ) phosphorylation and cytoplasmic translocation of AFX (a forkhead transcription factor), which downregulates p27 levels [19]. We used p110 $\alpha$ expression levels as a marker of PI3K expression and showed a significant downregulation of p110 $\alpha$ and p-Akt levels and an upregulation of p27 levels in bostrycin-treated A549 cells. These data suggest that p-Akt downregulation could inhibit cytoplasmic translocation of p27, causing a $\mathrm{G}_{1}$ cell cycle arrest of A549 cells. However, further studies are necessary to elucidate the mechanisms underlying bostrycin-mediated induction of apoptosis and attenuation of the PI3K/AKT signaling pathway in A549 cells. While we evaluated overall levels of phosphorylated Akt and p27 in this study, we would also like to detect changes in specific phosphorylation sites of these proteins, in order to more completely understand the mechanism of bostrycin action.

MicroRNAs are thought to play an important role in the development and progression of tumors [20]. Microarray analysis on 104 primary non-small cell lung carcinomas showed changes in the expression levels of 43 microRNAs in lung cancer tissue when compared with normal lung tissue [21]. Members of the let-7 family of microRNAs are known to inhibit growth of non-small cell lung carcinoma by inducing cell cycle arrest and apoptosis [22], while microRNA-126 inhibits the invasion of non-small cell lung carcinoma [23]. microRNA-25 and microRNA-205 have been used to predict survival and recurrence in lung cancer patients [24,25]. Exploring microRNA regulation may therefore provide useful information in developing new drug targets or identifying early disease markers [26]. MicroRNAs 638 and microRNA 923 were significantly upregulated in bostrycintreated A549 cells. Both microRNAs might be related with tumor inhibition.

Interestingly, microRNAs have also been reported to play a regulatory role in the PI3K signaling pathway. Recombinant microRNA-126 was shown to downregulate the expression of p85 $\beta$ (a regulatory subunit of PI3K related to the stabilization and transmission of the PI3K signal) and p-Akt proteins in rectal cancer cells [27], and microRNA-7 inhibited the Akt pathway and reduced survival rates in spongiocytoma [28]. It is tempting to speculate that upregulation of microRNA-638 and microRNA-923 in bostrycin-treated A549 cells, accompanied 
by downregulation of the PI3K/AKT signaling pathwayassociated proteins, $\mathrm{p} 110 \alpha$ and $\mathrm{p}$-Akt, are significantly related. We would like to dissect these pathways in greater detail in our upcoming studies, using luciferase assays to demonstrate direct targets of microRNA-638 and microRNA-923 in bostrycin-treated cells.

In conclusion, we demonstrated that bostrycin, a novel metabolite isolated from marine fungi, inhibited proliferation, blocked cell cycle progression and promoted apoptosis in pulmonary adenocarcinoma A549 cells. We also demonstrated 1) upregulation of tumor-suppressing transcriptional factors, the noncoding microRNA-638 and microRNA-923, and 2) downregulation of proteins associated with the PI3K/PI3K/AKT signaling pathway in bostrycin-treated cells, suggesting that bostrycin may be a new PI3K/AKT signal pathway-targeting drug for the treatment of pulmonary adenocarcinoma.

\section{Conflict of interests}

The authors declare that they have no competing interests.

\section{Additional material}

Additional file 1: Figure S1, Bostrycin (hydroxy-methoxy-tetrahydro5-methyl anthracene dione). The file contains the molecular chemical structure of bostrycin.

\begin{abstract}
Abbreviations
PI3K: Phosphoinositide 3-kinase; AKt/PKB: Protein Kinase B; mAb: monoclonal antibody; IC50: the half maximal inhibitory concentration.
\end{abstract}

\begin{abstract}
Acknowledgements
This work was supported by grants from The Natural Science Funds of Guangdong Province (7001646), and the Science and Technology Project of Guangdong Province (2008B080703022).

We thank the Marine Microorganism Laboratory, Institute of Chemistry and Chemical Engineering, Sun Yat-Sen University, for kindly providing the test compound, bostrycin; the Electron Microscope Center, North School Region, Sun Yat-Sen University, for the technical support with the electron microscope; Hangzhou Lianchuan Biological Message Ltd. Company for the technical support in gene chip and real-time RT-PCR techniques; and Dr. Tan $\mathrm{Li}$ (The Affiliated Tumor Research Centre of Sun Yat-Sen University) for the advice on western blotting.
\end{abstract}

\section{Author details \\ 'Department of Pulmonary and Critical Care Medicine, the First Affiliated Hospital of Sun Yat-Sen University, Guangzhou 510080, China. ${ }^{2}$ Department of Physiopathology, Zhongshan School of Medicine, Sun Yat-Sen University, Guangzhou 510080, China. ${ }^{3}$ Marine Microorganism Lab, Institute of Chemistry and Chemical Engineering, Sun Yat-Sen University, Guangzhou 510080, China.}

\section{Authors' contributions}

YBG: Conceived and designed the experiments;

WSC, JNH: Performed the experiments and analysed the data; $\mathrm{HLY}, \mathrm{CMX}, \mathrm{YCL}, \mathrm{ZGS}$ : Contributed reagents/material/analysis tools/. All authors read an approved the final draft.
References

1. Hodkinson PS, Mackinnon A, Sethi T: Targeting Growth Factors in Lung Cancer. Chest 2008, 133(5):1209-1216.

2. Mayer AM, Gustafson KR: Marine pharmacology in 2005-2006: antitumour and cytotoxic compounds. Eur J Cancer 2008, 44:2357-2387.

3. Lin W, Fang LK, Liu JW, Cheng WQ, Yun M, Yang HL: Inhibitory effects of marine fungal metabolites from the South China Sea on prostate cancer cell line DU-145. International Journal of Internal Medicine 2008, 35:562-564.

4. Chen CQ, Fang LK, Liu JW, Zhang JW, Yang GG, Yang W: Effects of marine fungal metabolites (1386A) from the South China Sea on proliferation, apoptosis and membrane potential of gastric cancer cell line MCG-803. Chinese Journal of Pathophysiology 2010, 26:1908-1912.

5. Hemstrom TH, Sandstrom M, Zhivotovsky B: Inhibitors of the PI3-kinase/ Akt pathway induce mitotic catastrophe in non-small cell lung cancer cells. Int J Cancer 2006, 119:1028-1038.

6. Sun SY, Zhou Z, Wang R, Fu H, Khuri FR: The farnesyltransferase inhibitor Lonafarnib induces growth arrest or apoptosis of human lung cancer cells without downregulation of Akt. Cancer Biol Ther 2004, 3:1092-1098, discussion 1099-1101.

7. Altomare DA, Testa JR: Perturbations of the AKT signaling pathway in human cancer. Oncogene 2005, 24:7455-7464.

8. Tsurutani J, Castillo SS, Brognard J, Granville CA, Zhang C, Gills JJ, Sayyah J, Dennis PA: Tobacco components stimulate Akt-dependent proliferation and NFkappaB-dependent survival in lung cancer cells. Carcinogenesis 2005, 26:1182-1195.

9. Nakanishi K, Sakamoto M, Yasuda J, Takamura M, Fujita N, Tsuruo T, Todo S, Hirohashi S: Critical involvement of the phosphatidylinositol 3-kinase/Akt pathway in anchorage-independent growth and hematogeneous intrahepatic metastasis of liver cancer. Cancer Res 2002, 62:2971-2975.

10. Tsurutani J, Steinberg SM, Ballas M, Robertson M, LoPiccolo J, Soda H, Kohno S, Egilsson V, Dennis PA: Prognostic significance of clinical factors and Akt activation in patients with bronchioloalveolar carcinoma. Lung Cancer 2007, 55:115-121.

11. Tang JM, He QY, Guo RX, Chang XJ: Phosphorylated Akt overexpression and loss of PTEN expression in non-small cell lung cancer confers poor prognosis. Lung Cancer 2006, 51:181-191.

12. Dimmeler S, Fleming I, Fisslthaler B, Hermann C, Busse R, Zeiher AM: Activation of nitric oxide synthase in endothelial cells by Akt-dependent phosphorylation. Nature 1999, 399:601-605.

13. Coffer PJ, Jin J, Woodgett JR: Protein kinase B (c-Akt): a multifunctional mediator of phosphatidylinositol 3-kinase activation. Biochem J 1998, 335(Pt 1):1-13.

14. Cardone MH, Roy N, Stennicke HR, Salvesen GS, Franke TF, Stanbridge E, Frisch S, Reed JC: Regulation of cell death protease caspase- 9 by phosphorylation. Science 1998, 282:1318-1321.

15. Brunet A, Bonni A, Zigmond MJ, Lin MZ, Juo P, Hu LS, Anderson MJ, Arden KC, Blenis J, Greenberg ME: Akt promotes cell survival by phosphorylating and inhibiting a Forkhead transcription factor. Cell 1999, 96:857-868.

16. Kane LP, Shapiro VS, Stokoe D, Weiss A: Induction of NF-kappaB by the Akt/PKB kinase. Curr Biol 1999, 9:601-604.

17. Muise-Helmericks RC, Grimes HL, Bellacosa A, Malstrom SE, Tsichlis PN, Rosen $\mathrm{N}$ : Cyclin D expression is controlled post-transcriptionally via a phosphatidylinositol 3-kinase/Akt-dependent pathway. J Biol Chem 1998, 273:29864-29872.

18. Miao LJ, Wang J, Li SS, Wu YM, Wu YJ, Wang XC: Correlation of P27 expression and localization to phosphorylated AKT in non-small cell lung cancer. Ai Zheng 2006, 25:1216-1220.

19. Chen Q, Ganapathy S, Singh KP, Shankar S, Srivastava RK: Resveratrol induces growth arrest and apoptosis through activation of FOXO transcription factors in prostate cancer cells. PLOS One 2010, 5:e15288.

20. Nana-Sinkam SP, Geraci MW: MicroRNA in lung cancer. J Thorac Oncol 2006, 1:929-931.

21. Yanaihara N, Caplen N, Bowman E, Seike M, Kumamoto K, Yi M, Stephens RM, Okamoto A, Yokota J, Tanaka T, Calin GA, Liu CG, Croce CM, Harris CC: Unique microRNA molecular profiles in lung cancer diagnosis and prognosis. Cancer Cell 2006, 9:189-198.

22. Kumar MS, Erkeland SJ, Pester RE, Chen CY, Ebert MS, Sharp PA, Jacks T: Suppression of non-small cell lung tumor development by the let-7 microRNA family. Proc Natl Acad Sci USA 2008, 105:3903-3908.

23. Crawford M, Brawner E, Batte K, Yu L, Hunter MG, Otterson GA, Nuovo G, Marsh CB, Nana-Sinkam SP: MicroRNA-126 inhibits invasion in non-small 
cell lung carcinoma cell lines. Biochem Biophys Res Commun 2008, 373:607-612.

24. Yu SL, Chen HY, Chang GC, Chen CY, Chen HW, Singh S, Cheng CL, Yu CJ, Lee YC, Chen HS, Su TJ, Chiang CC, Li HN, Hong QS, Su HY, Chen CC, Chen WJ, Liu CC, Chan WK, Li KC, Chen JJ, Yang PC: MicroRNA signature predicts survival and relapse in lung cancer. Cancer Cell 2008, 13:48-57.

25. Markou A, Tsaroucha EG, Kaklamanis L, Fotinou M, Georgoulias V,

Lianidou ES: Prognostic value of mature microRNA-21 and microRNA-205 overexpression in non-small cell lung cancer by quantitative real-time RT-PCR. Clin Chem 2008, 54:1696-1704.

26. Weiss GJ, Bemis LT, Nakajima E, Sugita M, Birks DK, Robinson WA, VarellaGarcia M, Bunn PA Jr, Haney J, Helfrich BA, Kato H, Hirsch FR, Franklin WA: EGFR regulation by microRNA in lung cancer: correlation with clinical response and survival to gefitinib and EGFR expression in cell lines. Ann Oncol 2008, 19:1053-1059.

27. Guo C, Sah JF, Beard L, Willson JK, Markowitz SD, Guda K: The noncoding RNA, miR-126, suppresses the growth of neoplastic cells by targeting phosphatidylinositol 3-kinase signaling and is frequently lost in colon cancers. Genes Chromosomes Cancer 2008, 47:939-946.

28. Kefas B, Godlewski J, Comeau L, Li Y, Abounader R, Hawkinson M, Lee J, Fine $\mathrm{H}$, Chiocca EA, Lawler S, Purow B: microRNA-7 inhibits the epidermal growth factor receptor and the Akt pathway and is down-regulated in glioblastoma. Cancer Res 2008, 68:3566-3572.

doi:10.1186/1756-9966-30-17

Cite this article as: Chen et al:: Bostrycin inhibits proliferation of human lung carcinoma A549 cells via downregulation of the PI3K/Akt pathway. Journal of Experimental \& Clinical Cancer Research 2011 30:17.

\section{Submit your next manuscript to BioMed Central} and take full advantage of:

- Convenient online submission

- Thorough peer review

- No space constraints or color figure charges

- Immediate publication on acceptance

- Inclusion in PubMed, CAS, Scopus and Google Scholar

- Research which is freely available for redistribution

Submit your manuscript at www.biomedcentral.com/submit
Biomed Central 